\title{
Immunogold co-localization of ovine placental lactogen and the antigen recognized by the SBU-3 monoclonal antibody in sheep placental granules*
}

\author{
C. S. Lee, F. B. P. Wooding† and M. R. Brandon \\ Department of Veterinary Preclinical Sciences, University of Melbourne, Parkville, Victoria 3052, \\ Australia, and $\dagger A F R C$ Institute of Animal Physiology, Babraham, Cambridge CB2 4AT, U.K.
}

\begin{abstract}
Summary. Ovine placental lactogen and the SBU-3 antigen (derived from a trophoblast membrane preparation), two proteins of widely different structure, function and destination, were shown by ultrastructural immunogold techniques to localize in identical structures in the sheep placentome throughout most of pregnancy. Both were restricted to the ultrastructurally similar membrane-bounded granules in the chorionic fetal binucleate cell and the syncytium at the fetomaternal interface. The Golgi body from which the granules form was also doubly labelled but only in the binucleate cell, never the syncytium. This provides further evidence that the binucleate cells migrate and fuse to form the syncytium. The two proteins were homogeneously distributed in the granules and would be released together by exocytosis. Only the lactogen reaches the fetal and maternal circulations so the SBU-3 may have some more local function.

In early pregnancy the SBU-3 antigen is found by itself in the granules, indicating that the association with the lactogenic hormone is not obligatory. Neither antigen was found consistently in the otherwise ultrastructurally similar interplacentomal binucleate cell granules, corroborating the presence of two functional populations of binucleate cells.
\end{abstract}

\section{Introduction}

All ruminant placentas studied so far have significant numbers of binucleate cells in the fetal trophectoderm from implantation to term (Amoroso, 1952; Wooding, 1982, 1983). Quantitative ultrastructural (Wooding, 1983), cytochemical (Wooding, 1980), autoradiographic (Wooding et al., 1981) and freeze-etch (Morgan \& Wooding, 1983) studies indicate that all mature binucleate cells migrate from the trophectoderm to form fetomaternal hybrid tissue and thereby deliver their characteristic granules for release into the maternal connective tissue.

Immunocytochemical studies of sheep have shown that the binucleate cells contain considerable amounts of at least two proteins, ovine placental lactogen (Martal et al., 1977; Watkins \& Reddy, 1980; Wooding, 1981) and a glycoprotein defined by a monoclonal antibody (SBU-3) raised against a trophoblast membrane preparation (Lee et al., 1985; Gogolin-Ewens et al., 1986; Lee et al., 1986a). At the light microscope level these proteins have been demonstrated to be present mainly in the binucleate cells and syncytium at the fetomaternal junction (Martal et al., 1977; Watkins \& Reddy, 1980; Lee et al., 1985), and ultrastructurally localized in similar membrane-bounded granules and the Golgi body from which the granules form in the binucleate cells (Wooding, 1981; Lee et al., 1986b).

\footnotetext{
${ }^{*}$ Reprint requests to Dr F. B. P. Wooding.
} 
However, ovine placental lactogen and the antigen recognized by SBU-3 appear to be quite different molecules on several criteria. Ovine placental lactogen is a protein molecule with no carbohydrate of $M_{\mathrm{r}} 22000$ (Chan et al., 1976) whereas the SBU-3 antigen ranges from $M_{\mathrm{r}} 27000$ to 200000 and always carries carbohydrate as covalently linked side chains (Gogolin-Ewens et al., 1986). Ovine placental lactogen is present in maternal and fetal sera through most of pregnancy (Chan et al., 1976; Martal \& Djiane, 1977), but it has not been possible to demonstrate the SBU-3 antigen in either circulation by quantitative absorption analysis at any stage (Gogolin-Ewens et al., 1986).

This paper reports an immunocytochemical investigation designed to establish whether ovine placental lactogen and the SBU-3 antigen were present in the same or separate granule populations in the binucleate cell and syncytium in the sheep placenta.

\section{Materials and Methods}

\section{Tissues}

Clun Forest or Soay sheep were killed with an overdose of pentobarbitone sodium at $29,36,41$, 87,123 and 140 days of pregnancy (days post coitum), one animal at each stage. The intact pregnant uteri were immediately removed and fixed by the procedures outlined by Wooding (1980). The uterine arteries were cannulated and perfused with $20 \mathrm{ml} 0.5 \%$ procaine in $0.1 \mathrm{M}$-Dulbecco phosphate saline (Dulbecco A tablets from Oxoid Ltd, Basingstoke, U.K.), followed by $250 \mathrm{ml}$ glutaraldehyde fixative. The uterus was then cut open, the fetal umbilical vessels cannulated and the fetal placental circulation perfused in a similar manner. Total perfusion time was 20 min at room temperature. Placentomal tissues were then cut into 1 to $2 \mathrm{~mm}$ slices and divided further into matchsticks which ran from top to bottom of the placentome. Tissues from interplacentomal areas were cut into $2-3 \mathrm{~mm}$ squares. All tissue pieces were placed in fixative for a further $45 \mathrm{~min}$ at room temperature and then stored at $4^{\circ} \mathrm{C}$ in the buffer in which the fixative was prepared.

The fixatives used were (1) $4 \%$ glutaraldehyde in $0.1 \mathrm{~m}$-Dulbecco phosphate saline $\mathrm{pH} 7 \cdot 2$ and $2 \%$ sucrose and (2) $2 \%$ glutaraldehyde in $0 \cdot 1 \mathrm{M}$-potassium phosphate buffer, pH $7 \cdot 2$. After fixation with 4 or $2 \%$ glutaraldehyde some tissue blocks were post-fixed in $1 \%$ osmium tetroxide in $0 \cdot 1 \mathrm{M}$-veronal acetate buffer, $\mathrm{pH} 7 \cdot 2$, for $1 \mathrm{~h}$. Others were embedded without osmium treatment. All pieces of fixed tissue were embedded in Araldite after dehydration in alcohol and propylene oxide (for details see Wooding, 1980).

\section{Immunology}

Antibodies. The monoclonal antibody SBU-3 was prepared by the fusion of spleen cells (from a BALB/c mouse hyperimmunized with a sheep trophoblast membrane preparation) with PS-NS/1/Ag 4-1 mouse myeloma cells as previously described (Lee et al., 1985). The labels used were 10 or $15 \mathrm{~nm}$ colloidal gold coated with goat anti-mouse antibodies (Janssen Pharmaceutica, Beerse, Belgium). These were diluted 1:20 in PBS.

The rabbit antiserum to ovine placental lactogen was a gift from Professor $\mathrm{H}$. G. Friesen, Manitoba, Winnipeg, Canada. Details of this preparation are given by Chan et al. (1978). The antiserum was diluted to 1:200 with PBS containing 5\% normal sheep serum. The labels used were 5 or $10 \mathrm{~nm}$ colloidal gold coated with goat anti-rabbit antibodies (Janssen). These were diluted 1:30 in PBS.

Double-labelling technique. The 70-100 nm Araldite sections used were mounted on 300 mesh uncoated nickel grids. The dull surface of the grid, the face where the tissue sections are completely exposed, was used for SBU-3, whereas the shining surface, the surface where the tissue sections are 
exposed only between the bars of the grid, was used for antiserum to ovine placental lactogen. After being washed with a few drops of PBS, the grids were floated with the dull surface facing downwards on a drop of SBU-3 supernatant for $30 \mathrm{~min}$ at room temperature. Following this the grid was washed with PBS before being floated on a drop of goat anti-mouse colloidal gold for another $30 \mathrm{~min}$ at room temperature. The grid was washed with PBS, then distilled water and allowed to dry for $30 \mathrm{~min}$ at room temperature. The shiny surface of the grid was exposed to a drop of antiserum to ovine placental lactogen and the colloidal gold-labelled goat anti-rabbit antibodies in the same manner as described for the dull surface. In some instances only one surface, the dull surface was used. In this situation the drop of the first antibody solution contained a mixture of an equal volume of SBU-3 and antiserum to ovine placental lactogen, and the drop of second antibody solution contained a mixture of an equal volume of goat anti-mouse colloidal gold and goat anti-rabbit colloidal gold.

To facilitate localization of the granules in binucleate cells and syncytium, sections were stained with $1 \%$ phosphotungstic acid (PTA) in $35 \% \mathrm{HCl}$ for $15 \mathrm{~min}$ at $60^{\circ} \mathrm{C}$ (Wooding, 1980). This was occasionally followed by staining with a saturated solution of uranyl acetate in $50 \%$ alcohol for $15 \mathrm{~min}$ at $20^{\circ} \mathrm{C}$. For controls $1 \%$ whole sheep, mouse or rabbit serum (heated at $60^{\circ} \mathrm{C}$ for $30 \mathrm{~min}$ to remove complement) was substituted for SBU-3 or antiserum to ovine placental lactogen. Absorption of antiserum to ovine placental lactogen with purified placental lactogen (Wooding, 1981) completely abolished gold labelling due to lactogen.

Method of counting. The percentages of positive and negative binucleate cells and syncytium were determined by counting on sections in the electron microscope as previously described (Lee $e t$ al., 1986b). A cell was scored as doubly labelled when the majority of its granules were seen to contain at least 3 gold particles of each size. The percentages of positive and negative binucleate cells in the interplacentomal areas were also determined by the same method of counting.

The sheep syncytium is divided into plaques by tight junctions (Wooding, 1984). To avoid two counts on one plaque, granule-containing areas up to twice as long as the diameter of a binucleate cell were taken as one cell or unit, and only two such units, as far apart as possible, were counted in any one 300 mesh grid square.

\section{Results}

As shown in Table 1 double immunogold labelling of individual granules of the binucleate cells and syncytium was observed only when both antisera and both gold labels had been used sequentially (treatment 1) or simultaneously (treatment 5). The results were similar, indicating that there was no appreciable cross-reactivity between the two primary and/or gold-labelled antisera tested, but the data presented are based mainly on the sequential procedure (treatment 1) since this produced lower background labelling. Since the SBU-3 specific antigen does not survive osmium fixation (Lee et al., 1986b) the data on co-localization was based on tissues fixed only in glutaraldehyde and the sections stained only with PTA. The concentration of glutaraldehyde used had no effect on the labelling level of either antigen. The PTA staining of the sections allows a straightforward recognition of all types of cells and tissue architecture but the image lacks membrane definition and background detail (Figs lc, 3b, 4a). This is an advantage in this context for it greatly facilitates the search for significant localization of gold labelling over large areas of section and enables all the granules to be easily recognized and checked. The low cytoplasmic contrast is not due to poor fixation since osmicated blocks from the same specimens used for the double labelling show good ultrastructural detail.

The gold particle sizes $(5$ or $10 \mathrm{~nm}$ for antiserum to ovine placental lactogen and 10 or $15 \mathrm{~nm}$ for SBU-3) used were easily distinguishable over the characteristic PTA-staining granules of the binucleate cells (Figs la, 3a) and similar granules in the syncytium (Figs 2, 3b, 3c). The only other 
Table 1. Protocols used to establish the specificity of the co-localization of ovine placental lactogen (oPL) and the SBU-3 antigen

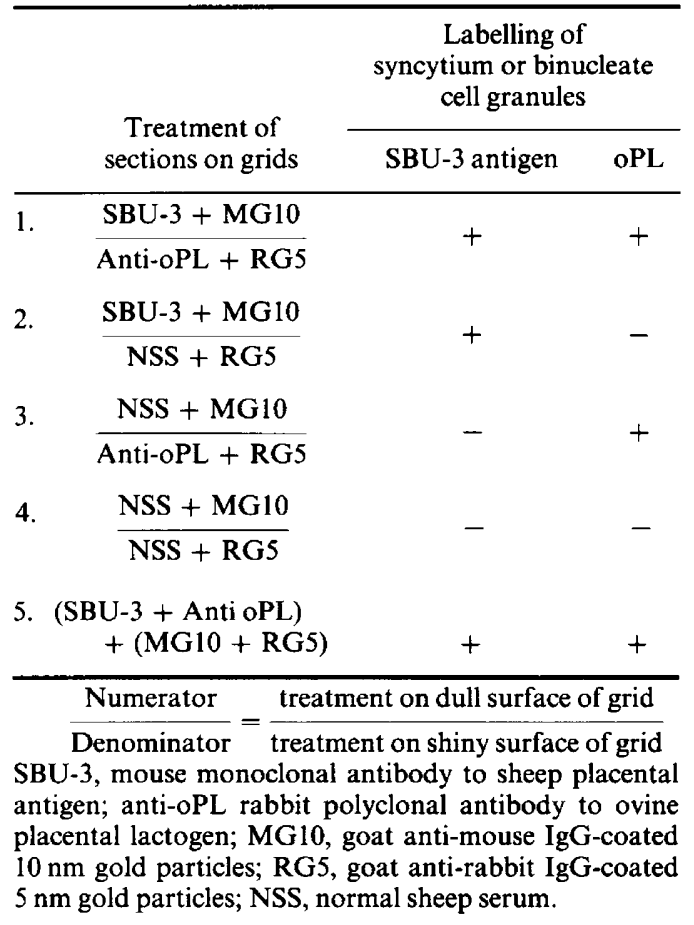

organelle showing a significant localization of gold particles of both sizes was the Golgi body of the binucleate cell (Fig. 1b). Gold particles of both sizes were occasionally found over other placental cell organelles, connective tissues or extracellular space, but they were never above the background levels observed in the controls in which $1 \%$ sheep, mouse or rabbit serum was used in place of the SBU-3 or ovine placental lactogen.

At 87,123 and 140 days of pregnancy all placentomal binucleate cells had granules labelled at similar levels with gold particles of both sizes (Table 2). The percentages of double-labelled binucleate cells increased sharply from an insignificant $1 \%$ at Day 29 to $57 \%$ by Day 36 . At these early stages binucleate cell granules labelled only with SBU-3 were seen but reactivity with ovine placental lactogen was never found to occur by itself during this study. The sheep killed at 41 days p.c. had far fewer doubly-labelled binucleate cells; most were labelled only with SBU-3 (Figs 4a, b, c). However, at the light microscope level the placentomes appeared to be less developed than those of the animal killed at 36 days p.c.

There was occasional clumping of the $5 \mathrm{~nm}$ gold particles but overall the distribution of gold particles of both sizes over the binucleate cell granules was even (Figs 1a, 3a). The intensity of granule labelling on any one section was fairly uniform with some variation between and within

Figs $1 \& 2$. Immunogold co-localization of SBU-3 antigen $(10 \mathrm{~nm}$ gold) and ovine placental lactogen ( $5 \mathrm{~nm}$ gold) in granules (a) and Golgi body (b) of a binucleate cell similar to the one shown in (c) and in granules of the syncytium (Fig. 2). Note the homogeneous distribution of both labels over the granules but the sparse labelling of the Golgi body cis (forming face) cisternae (asterisks). G, Golgi body; N, nucleus. Sheep placentome 87 days p.c. Fig. 1(a), $\times 45000$; Fig. 1(b) $\times 40000$; Fig. 1(c) $\times 2400$; Fig. $2 \times 45000$. 


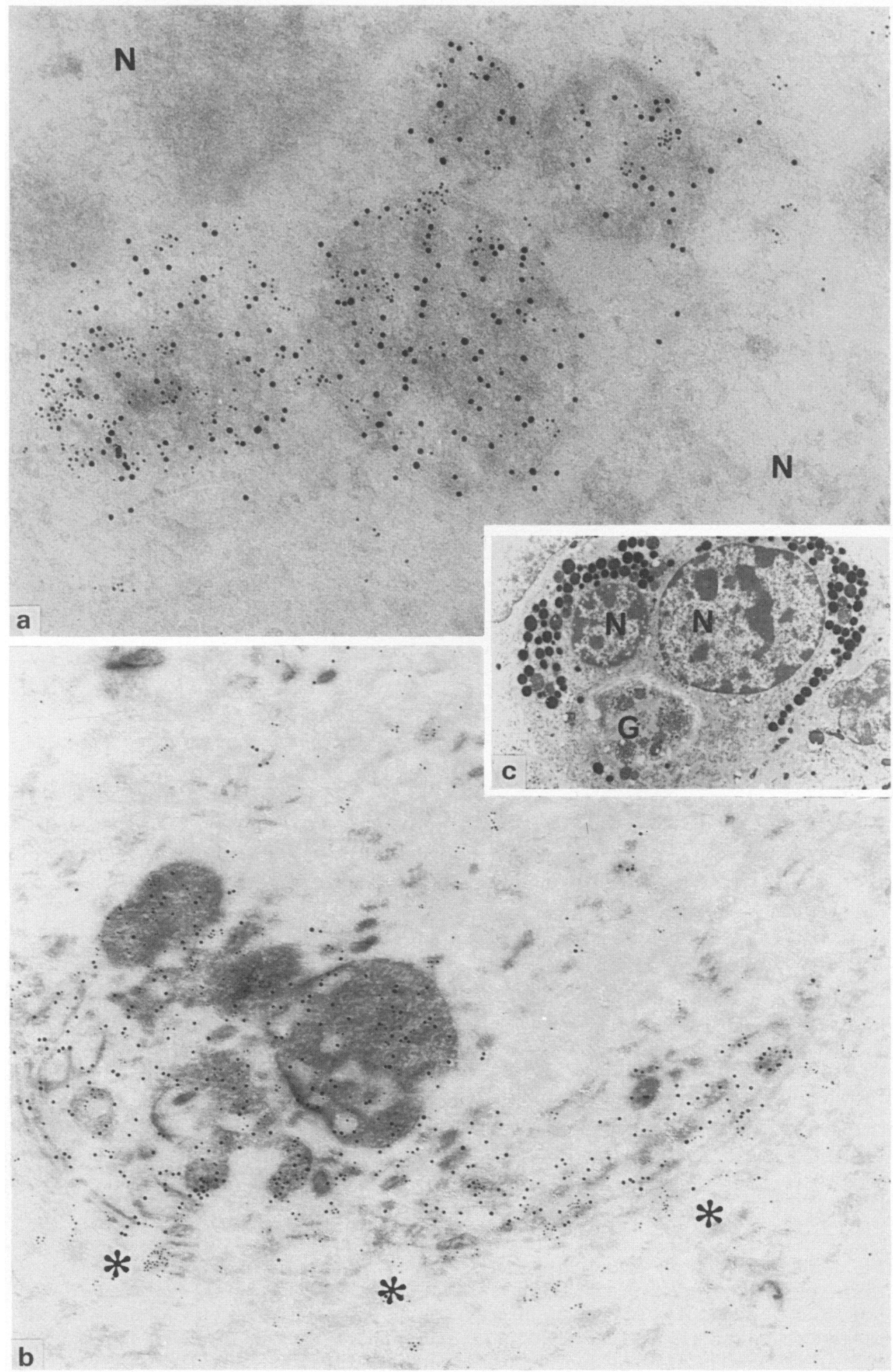

Fig. 1. 


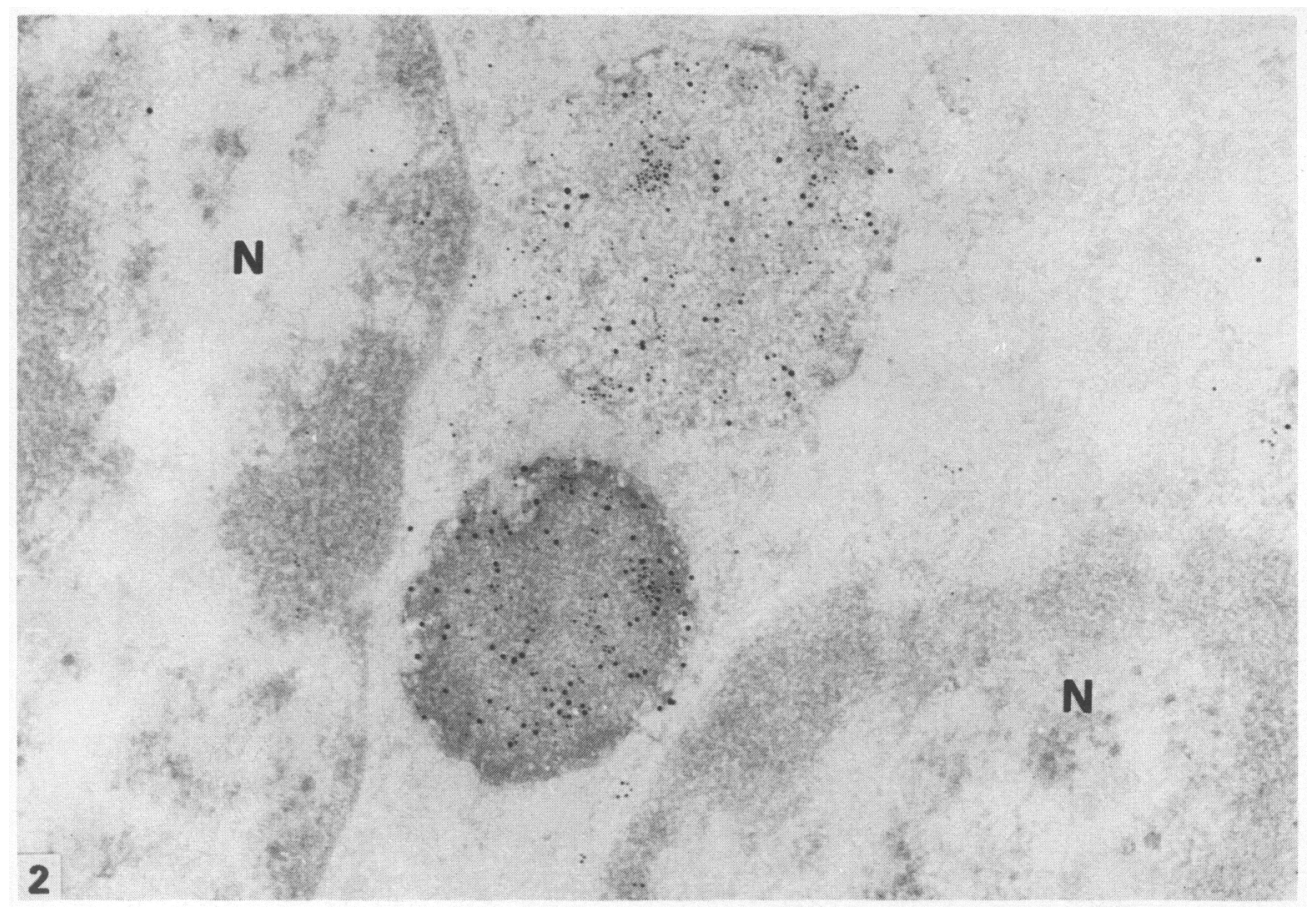

Fig. 2.

cells, but always well above the background level in the controls. Granules with more intense labelling with antiserum to ovine placental lactogen than with SBU-3, and vice versa, were sometimes observed. There was an equivalent distribution of gold particles of both sizes on the granules of non-migrating and migrating binucleate cells.

In the syncytial plaques at Days $36,87,123$ and 140 p.c. the great majority $(75-100 \%)$ of the granules were doubly labelled (Figs 2, 3c) (Table 2). Syncytia were seen with granules labelled only with SBU-3 at 36 days p.c. ( $5 \%$ ), and 41 days p.c. (99\%) (Fig. 4c). The size, structure and variation of labelling of the granules were equivalent to that observed in the binucleate cells in the trophectoderm. At 29 days p.c., the earliest stage of pregnancy examined, the granules of the syncytium were not labelled by SBU-3 or antiserum to ovine placental lactogen.

No labelling of any kind was observed in the binucleate cells or syncytium in the interplacentomal area (Table 2).

Fig. 3. Immunogold co-localization of SBU-3 antigen ( $15 \mathrm{~nm}$ gold) and ovine placental lactogen ( $5 \mathrm{~nm}$ gold) in the granules of a migrating binucleate cell (asterisk in b, and a) and granules in the syncytium ( $\mathrm{S}, \mathrm{c}$ and $\mathrm{b}$ ) into which the binucleate cell is migrating. The arrows in the inset are in the same relative positions as those in (a) and (c) and indicate the same granules. The granules without gold label in (a) are lysosomes $(\mathrm{L})$ in the adjacent uninucleate cell of the fetal trophoblast (T). The microvillar junction between trophoblast (T) and syncytium (S) in (b) is indicated by small arrowheads. Sheep placentome 120 days p.c. (a) $\times 63000$; (c) $\times 52000$; (b) $\times 2200$. 


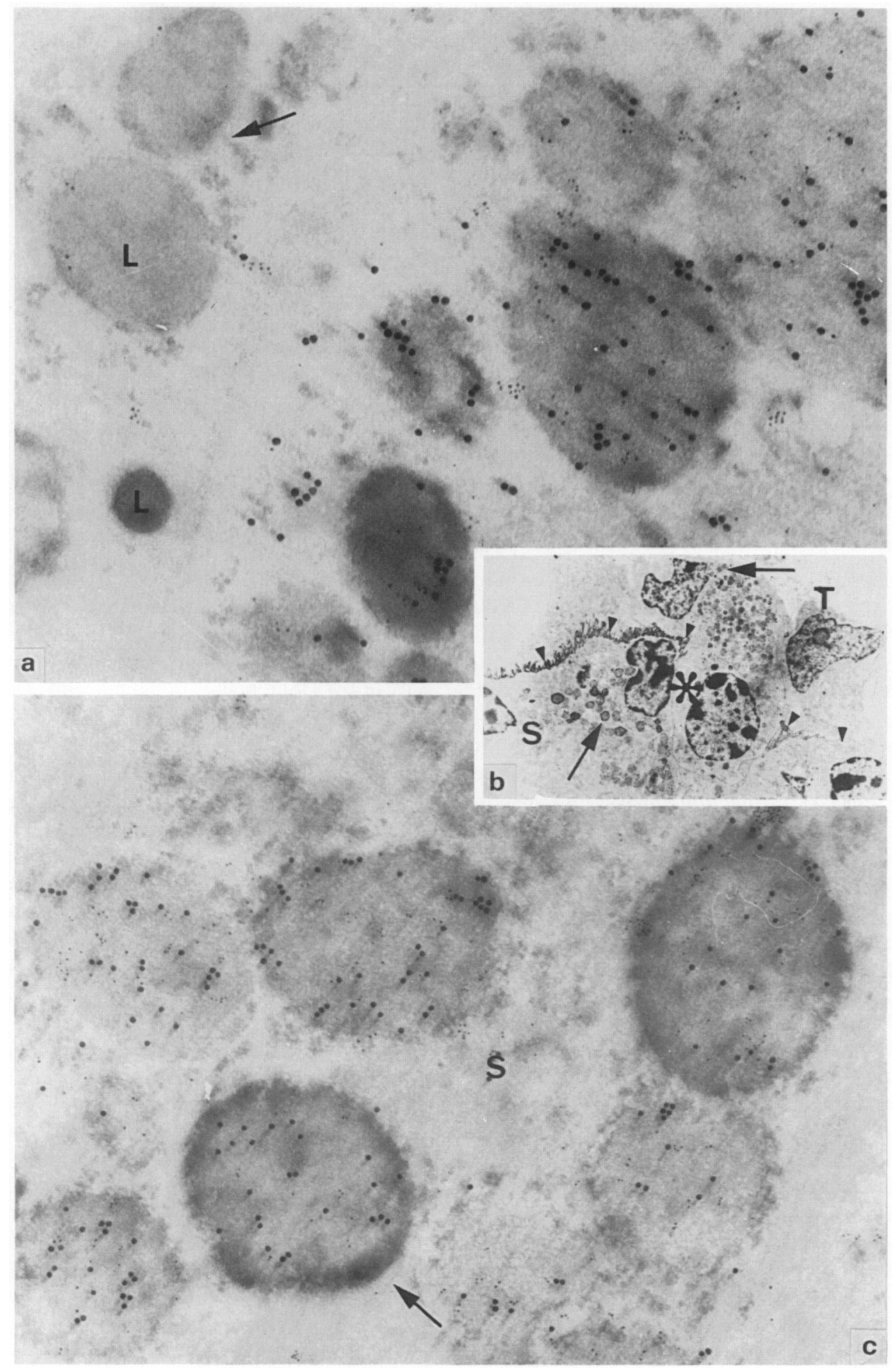

Fig. 3. 
Table 2. Percentages of singly (SBU-3 positive) and doubly labelled (SBU-3 and anti-ovine placental lactogen-positive) cells in the placentome and interplacentomal areas in the sheep

\begin{tabular}{|c|c|c|c|c|c|c|c|c|}
\hline \multirow[b]{3}{*}{$\begin{array}{l}\text { Day of } \\
\text { pregnancy }\end{array}$} & \multicolumn{4}{|c|}{ Placentome } & \multicolumn{4}{|c|}{ Interplacentome } \\
\hline & \multicolumn{2}{|c|}{ Binucleate } & \multicolumn{2}{|c|}{ Syncytium } & \multicolumn{2}{|c|}{ Binucleate } & \multicolumn{2}{|c|}{ Syncytium } \\
\hline & SBU-3 & $\begin{array}{l}\text { SBU-3 and } \\
\text { anti-oPL }\end{array}$ & SBU-3 & $\begin{array}{l}\text { SBU-3 and } \\
\text { anti-oPL }\end{array}$ & SBU-3 & $\begin{array}{l}\text { SBU-3 and } \\
\text { anti-oPL }\end{array}$ & SBU-3 & $\begin{array}{l}\text { SBU-3 and } \\
\text { anti-oPL }\end{array}$ \\
\hline 29 & 2 & $1\left(60^{*}\right)$ & 0 & $0(20)$ & 0 & $0(30)$ & 0 & $0(30)$ \\
\hline 36 & 36 & $57(54)$ & 5 & $75(20)$ & 0 & $0(30)$ & 0 & $0(30)$ \\
\hline 41 & 83 & $5(84)$ & 99 & $1(72)$ & 0 & $0(40)$ & & NF \\
\hline 87 & 0 & $100(100)$ & 0 & $100(40)$ & 0 & $0(30)$ & & NF \\
\hline 123 & 0 & $100(100)$ & 0 & $100(100)$ & 0 & $0(30)$ & & NF \\
\hline 140 & 0 & $100(100)$ & 0 & $100(40)$ & 0 & $0(20)$ & & NF \\
\hline
\end{tabular}

NF: no syncytium found, at least $4000 \mu \mathrm{m}$ of interplacentomal uterine epithelium examined.

* Number of cells or syncytial areas counted, some cells at 29,36 and 41 days p.c. were labelled with neither antibody; sequential immunocytochemical procedure used throughout.

\section{Discussion}

This report clearly demonstrates that ovine placental lactogen and the SBU-3 antigen are present together in the same $0.3-0.6 \mu \mathrm{m}$ granules in the fetomaternal interface layers of the sheep placentomes. Their sharply exclusive co-localization in the characteristic phosphotungstic acid-staining granules in both syncytium and binucleate cell but only in the Golgi bodies in the binucleate cells, lends further support to the hypothesis of binucleate cell migration from the trophectoderm to form the syncytium after synthesis of the granules is completed (Wooding, 1982; Lee et al., 1985).

Ovine placental lactogen and SBU-3 antigen reactivity are found evenly mixed in the placentomal granules throughout most of pregnancy but neither could be demonstrated in significant amounts before 30 days p.c. although fully granulated binucleate cells and syncytial areas are present from 16 days p.c. in the sheep. At the early stages SBU-3 reactivity was found without that of the lactogen, but never the lactogen without SBU-3, suggesting that the SBU-3 antigen synthesis can be independently controlled and precedes synthesis of ovine placental lactogen. There were some morphological indications that the placentomes of the animal killed at 36 days p.c. were at a later developmental stage than those of the animal at 41 days p.c. This may explain the lack of lactogen in the latter.

In interplacentomal areas neither antigen was found in binucleate cell granules in this study and this supports our previous suggestion of two populations of binucleate cells. However, Watkins \& Reddy (1980) reported the presence of ovine placental lactogen in a small number of interplacentomal binucleates using light microscope immunoperoxidase methods. Because of sampling problems when looking for small numbers using electron microscopy it is possible that we may have missed the few interplacentomal binucleate cells with ovine placental lactogen and/or SBU-3 antigen in their granules but think it unlikely that they would amount to more than 5-10\% of binucleate cells in this region.

When considering how early the placental lactogen and SBU-3 reactivity can be demonstrated or when interpreting negative results it must be remembered that the post-embedding immunogold technique is probably less sensitive than other types of assay. Radioimmunoassay and radioreceptor assays (Martal \& Djiane, 1977) have both shown that ovine placental lactogen can be detected in the sheep blastocyst as early as 15-16 days p.c., correlating well with first appearance of granulated binucleate cells. The results in this paper may indicate the limits of sensitivity of detection rather than the true absence or first appearance of molecules of the relevant specificity. 

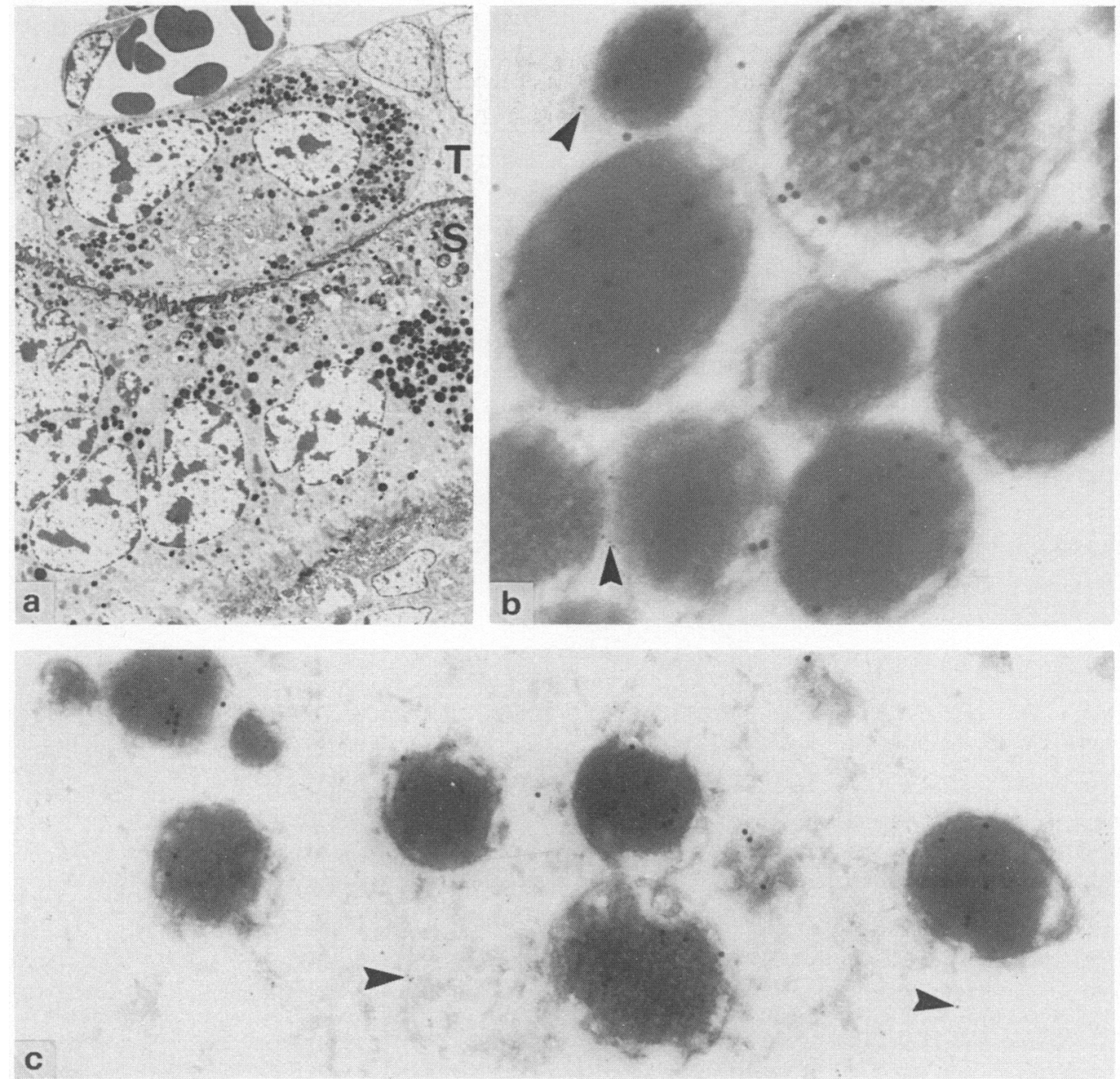

Fig. 4.

Fig. 4. (a) Low power view of trophoblast (T) and syncytium (S) in a 41 days p.c. sheep placentome. SBU-3 antigen can be localized at a low level by the $10 \mathrm{~nm}$ gold particles in granules in binucleate cells (b) and syncytium (c). No significant ovine placental lactogen gold labelling $(5 \mathrm{~nm})$ can be seen over the granules, only background levels of $5 \mathrm{~nm}$ particles are visible (arrowheads). (a) $\times 2000$; (b) $\times 66000$; (c) $\times 50000$.

There is no evidence that there is any obligate relationship between the two proteins, ovine placental lactogen and the SBU-3 antigen. They differ in structure, function and their destination after granule release. They unquestionably co-localize in the granules, so they could be products of the same mRNA, like oxytocin and neurophysin which occur in the same population of granules in the sheep corpus luteum (Theodosis et al,, 1986), but with only one (placental lactogen) reaching the circulation. Alternatively, the SBU-3 antigen could be a packaging or sorting protein for the lactogen peptide hormone. Antigens which cross-react with SBU-3 have been found in all ruminant binucleate cell granules so far examined (Lee et al., 1985, 1986a) but the different placental lactogen antibodies show no cross-reaction when tested immunocytochemically. Such a system using a common packaging or sorting protein with different hormones would be analogous to the glutamic acid rich protein common to granules in different cells of the cow pituitary, each of which contains 
a different hormone (Rosa et al., 1985). It is not yet known whether the structure of the SBU-3 antigen is suitable for such a role.

The use of PTA staining simplifies the search for gold particle localization because of the low general contrast and selective staining of the granules. However, the consequent lack of membrane definition has precluded identification of sites of exocytosis and no micrographic evidence for extracellular ovine placental lactogen or SBU-3 antigen was observed in this study. Some evidence has been presented previously for exocytosis from the syncytium at the early stages of cotyledon formation in the sheep (Wooding, 1984) and it remains the most likely explanation for the presence of placental lactogen in the maternal circulation throughout pregnancy. Granule exocytosis would also release the SBU-3 antigen which cannot be detected in the maternal circulation and a strictly local role in facilitating villus growth into the caruncle has been suggested (Lee et al., 1985, 1986a). However, the strict co-localization of the two antigens for the last two thirds of pregnancy and their absence from the intercotyledonary areas in sheep and goats may indicate some functional association between them.

We thank G. Morgan, M. Peacock and S. Johnson for invaluable technical assistance.

\section{References}

Amoroso, E.C. (1952) Placentation. In Marshall's Physiology of Reproduction, 3rd edn, Vol. 2, pp. 127-311. Ed. A. S. Parkes. Longmans Green, London.

Chan, J.S.D., Robertson, H.A. \& Friesen, H.G. (1976) The purification and characterisation of ovine placental lactogen. Endocrinology, 98, 65-76.

Chan, J.S.D., Robertson, H.A. \& Friesen, H.G. (1978) Maternal and fetal concentrations of ovine placental lactogen measured by radioimmunoassay. Endocrinology, 102, 1606-1613.

Gogolin-Ewens, K.J., Lee, C.S., Mercer, W.R., Moseby, A.M. \& Brandon, M.R. (1986) Characterisation of a trophoblast specific molecule. Placenta 7, 243-256.

Lee, C.S., Gogolin-Ewens, K., White, T.R. \& Brandon, M.R. (1985) Studies on the distribution of binucleate cells in the placenta of the sheep with a monoclonal antibody, SBU-3. J. Anat. 140, 565-575.

Lee, C.S., Gogolin-Ewens, K. \& Brandon, M.R. (1986a) Comparative studies on the distribution of binucleate cells in the placenta of the deer and cow using the monoclonal antibody SBU-3. J. Anat. (in press).

Lee, C.S., Wooding, F.B.P. \& Brandon, M.R. (1986b) Ultrastructural immunogold investigation of the function and diversity of binucleate cells in the ovine placenta using a monoclonal antibody. Placenta (In press).

Martal, J. \& Djiane, J. (1977) The production of chorionic somatomammotrophin in the sheep. $J$. Reprod. Fert. 49, 285-289.

Martal, J., Djiane, J. \& Dubois, M.P. (1977) Immunofluorescent localisation of ovine placental lactogen. Cell Tissue Res. 184, 427-433.

Morgan, G. \& Wooding, F.B.P. (1983) Cell migration in the ruminant placenta, a freeze fracture study. $J$. Ultrastruct. Res. 83, 148-160.
Rosa, P., Fumagalli, G., Zanini, A. \& Huttner, W.B. (1985) The major tyrosine-sulfated protein of the bovine anterior pituitary is a secretory protein present in gonadotrophs, thyrotrophs, mammotrophs and corticotrophs. J. Cell Biol. 100, 928-937.

Theodosis, D.T., Wooding, F.B.P., Sheldrick, E.L. \& Flint, A.P.F. (1986) Ultrastructural localisation of oxytocin and neurophysin in the ovine corpus luteum. Cell Tissue Res. 243, 129-135.

Watkins, W.B. \& Reddy, S. (1980) Ovine placental lactogen in the cotyledonary and intercotyledonary placenta of the ewe. J. Reprod. Fert. 58, 411-414.

Wooding, F.B.P. (1980) Electronmicroscopic localisation of binucleate cells in the sheep placenta using phosphotungstic acid. Biol. Reprod. 22, 357-365.

Wooding, F.B.P. (1981) Localisation of ovine placental lactogen in sheep placentomes by electron microscope immunocytochemistry. J. Reprod. Fert. 62, 15-19.

Wooding, F.B.P. (1982) The role of the binucleate cell in ruminant placental structure. J. Reprod. Fert., Suppl. 31, 31-39.

Wooding, F.B.P. (1983) Frequency and localisation of binucleate cells in the placentomes of ruminants. Placenta 4, 527-540.

Wooding, F.B.P. (1984) Role of binucleate cells in fetomaternal cell fusion at implantation in the sheep. Am. J. Anat. 133, 233-250.

Wooding, F.B.P., Flint, A.P.F., Heap, R.B. \& Hobbs, T. (1981) Autoradiographic evidence for migration and fusion of cells in the sheep placenta: resolution of a problem in placental classification. Cell Biol. Int. Rep. $5,821-827$. 